\title{
Assessment of Productivity Status Using Carlson's TSI and Fish Diversity of Goronyo Dam, Sokoto State, Nigeria
}

\author{
Hassan Muhammad Maishanu ${ }^{1}$, Muhammad Murtala Mainasara ${ }^{2}$, Ibrahim Muhammad Magami ${ }^{1}$ \\ ${ }^{1}$ Usmanu Danfodiyo University \\ P. M. B. 2346, Sokoto, Nigeria \\ ${ }^{2}$ Universiti Tun Hussein Onn Malaysia \\ 101 Beg Berkunci, Parit Raja, Batu Pahat, Johor, 86400, Malaysia
}

DOI: $10.22178 /$ pos.30-3

LCC Subject Category:

SH201-399

Received 05.12.2017

Accepted 08.01.2018

Published online 10.01.2018

Corresponding Author:

Muhammad Murtala Mainasara

mmgusau96@gmail.com

(C) 2018 The Authors. This article is licensed under a Creative Commons Attribution 4.0 License

\begin{abstract}
Goronyo Dam is the largest lentic waterbody in Sokoto, it was constructed to serve as flood control and used for irrigation activities. The study was conducted to evaluate productivity status and fish diversity of Goronyo Dam in 2016. Water samples were collected monthly from the Dam at two sampling sites (Upstream and Downstream). Water samples were collected using sterilized sampling bottles and analyzed in the Laboratory for physicochemical variables and the diversity of fish was evaluated through the use of a structured questionnaire. Depth and transparency were the only variables that did not show any statistically significant difference between the months. Productivity status of the dam was evaluated using Carlson's Trophic State Index. The downstream has high TSI value of 16.54 compared to upstream with 13.00. A diversity of fishes from the shows that 3 species were more abundant in the dam, these were; Mormyrops species, Alestes species and Clupeid species. Factors contributed to the survival of fish species were an abundance of water and plankton in the dam. While factors affecting the distribution of fish species were pollution and predation.
\end{abstract}

Keywords: downstream; fish; Goronyo; productivity; upstream.

\section{INTRODUCTION}

Primary productivity is the rate, at which the sun's radiant energy stored by photosynthetic and chemosynthetic activities of producers in the form of organic substances. The Knowledge of phytoplankton and nutrient concentration are fundamental to the understanding of ecosystem dynamics [3].

The productivity in terms of planktonic biomass in freshwater bodies is regulated by various physicochemical factors viz., temperature, transparency, $\mathrm{pH}$, total hardness, especially nitrogen and phosphates etc. [1]. Primary production by algae in the water and on the bottom of lakes sets the level of food available for secondary producers, such as zooplankton and fish. Primary production is controlled by a combination of temperature, light and nutrients. When nutrient availability is high, overall production varies with water temperature and nutrients [7, 15]. When nutrient availability is low, the overall production is set by the nutrient level and is relatively insensitive to changes in temperature $[6,15]$. It is likely that rates of primary production will be altered by climate change and may result in significant consequences for aquatic ecosystems and the human communities that use them. On the one hand, decreases in primary production will reduce food availability at the bottom of the food web, ultimately causing reductions in productivity of fish at the top of the food web. On the other hand, excessive increases in primary production will produce eutrophic (highly productive) conditions, exemplified by degraded water quality and noxious blue-green algal blooms [17].

Trophic State Index refers to the level of productivity in a lake as measured by phosphorous, algae abundance and depth of light penetration. TSI rates individual lakes, ponds and reservoirs 
based on the amount of biological productivity occurring in the water. Using the index, one can get a quick idea about the extent of productivity of a lake [11].

The most commonly used method on the productivity of the water body is the biomass related trophic state index developed [4]. Carlson's Trophic State Index (TSI) is a common method for characterizing lake's trophic status. This method uses Secchi disc transparency, chlorophyll- $a$, and phosphorus measurements [5].

\section{MATERIALS AND METHOD}

\section{Study Area}

Goronyo Dam is located in Goronyo LGA of Sokoto State. The dam channels cut across the entire 11 political wards (lowest administrative unit). Its reservoir covers an area of about 20,000 hectares and irrigates a minimum of 50,000 hectares. It has three major concrete-lined canals with several secondary and tertiary unlined canals with an approximate total length of more than $100 \mathrm{~km}$ [16]. Goronyo Dam impounds (which separate Upstream and Downstream) River Rima. It was completed in 1984 and commissioned in 1992. The dam is a sand-fill structure with a height of $21 \mathrm{~m}$ and a total length of $12.5 \mathrm{~km}$. It has a storage capacity of 976 million cubic meters (Figure 1).

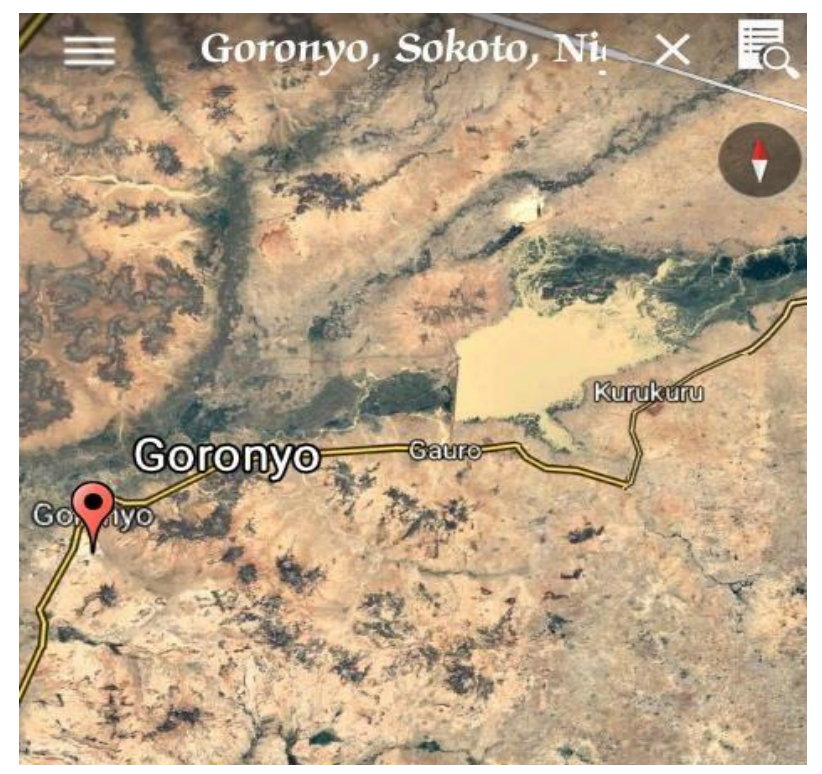

Figure 1 - Goronyo Dam through Google Earth

The dam is important for controlling floods and releasing water through the downstream (Fig- ure 2) in the dry season for the planned Zauro polder project downstream in Kebbi State.

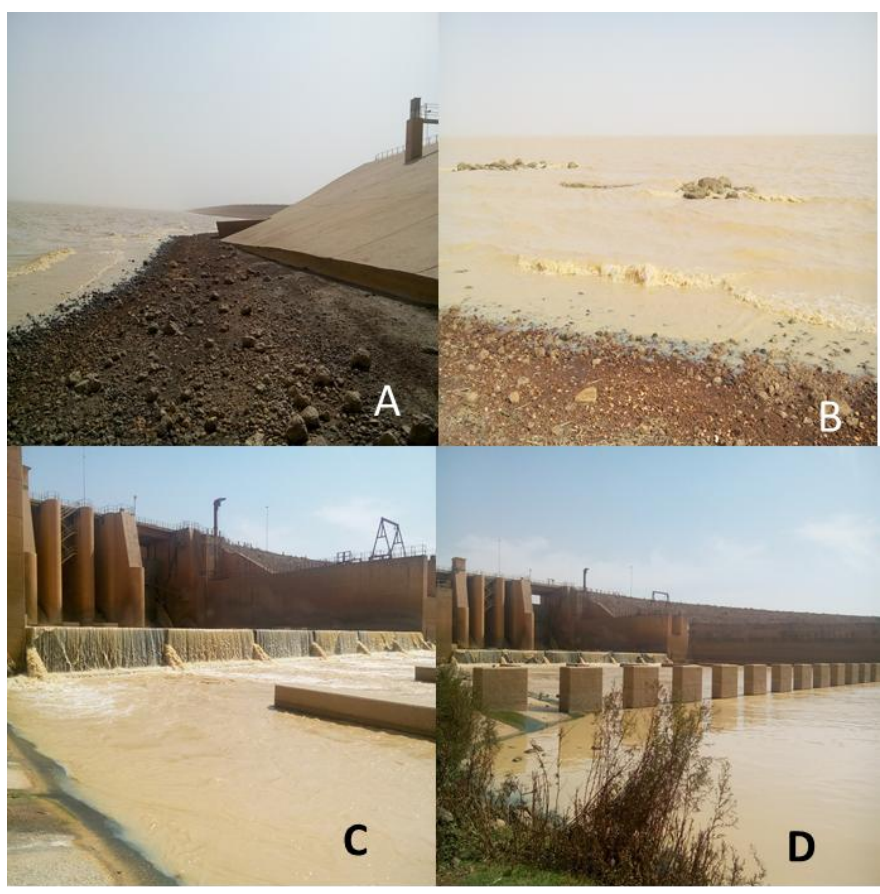

Figure 2 - Goronyo Dam Showing Upstream (A-B) and Downstream (C-D)

\section{Sample Collection}

Water sample was collected monthly from June to August 2016, which were both collected from upstream and downstream in a sterilized sampling bottles. These were taken immediately to the Laboratory, analysis, while temperature, transparency and depth were determined in situ.

\section{Determination of Physicochemical Parameters}

Physicochemical variables were determined and recorded according to standard methods; $\mathrm{pH}$ and Electric conductivity were measured using their respective meters, Winkler method was used for determination of Dissolve oxygen and Biological Oxygen Demand. Distillation with the Microkjeldahl distillator was used for determination of nitrate $\left(\mathrm{NO}_{3}\right)$ and ammonia. Phosphate and chlorophyll- $a$ were determined with spectrophotometer at 660 wavelengths, standard methods [2]. While determination of Trophic Status Index (TSI) was evaluated according Carlson's computation as follows:

a) TSI for Chlorophyll- $a$ (CA)

TSI $=9.81$ In X Chlorophyll $-a+30.6$

b) TSI for Secchi depth (SD)

TSI = 60-14.41 In X Secchi depth 
c) TSI for Total phosphorus (TP)

TSI = 14.42 In X Total phosphorous + 4.15.

where TSI is Carlson Trophic Status Index and In is Natural logarithm.

Carlson's Trophic Status Index (TSI) =

$$
\frac{T C I(T P)+T S I(C A)+T C I(S D)}{3} \text {. }
$$

Any value obtained was used following Carlson TSI lakes classification [4].

\section{Survey of Fish Diversity}

The diversity of fishes was evaluated with the use of structured questionnaire; this was distributed to fishermen randomly at the landing sites around the Dam. The responses were collated and analyzed.

\section{Statistical Analysis}

Data collected were subjected to Analysis of Variance (ANOVA) using the SPSS version 20.0 (Special Packages for Social Sciences) and Paired T-test was carried out to determine the variation between the two sites (Upstream and Downstream), according to [8].

\section{RESULTS AND DISCUSSION}

Physicochemical characteristics of water are important determinant for the status any aquatic system, these important characteristics are greatly influenced by climatic vegetation and general composition of water. The present study was carried out during the months of June to $\mathrm{Au}-$ gust, 2016.

Results from the present study, reveals that the physical factors such as Temperature fluctuated from $26^{\circ} \mathrm{C}$ to $28^{\circ} \mathrm{C}$ to $29^{\circ} \mathrm{C}$ in Upstream and from $28{ }^{\circ} \mathrm{C}$ to $29^{\circ} \mathrm{C}$ to $31{ }^{\circ} \mathrm{C}$ in Downstream respectively from June to August. Temperature values were recorded during the study period, though $27.7^{\circ} \mathrm{C}$ and $29.3^{\circ} \mathrm{C}$ were obtained at upstream and downstream respectively.

The results also reveal that there wasn't a significant difference between upstream and downstream for temperature measurement. Depth fluctuated from $9.5 \mathrm{~m}$ to $11.5 \mathrm{~m}$ to $14 \mathrm{~m}$ in Up- stream and from $3 \mathrm{~m}$ to $4 \mathrm{~m}$ to $5.5 \mathrm{~m}$ in Downstream; Transparency fluctuated from $21 \mathrm{~cm}$ to $23 \mathrm{~cm}$ to $30 \mathrm{~cm}$ in Upstream and from $12 \mathrm{~cm}$ to $13 \mathrm{~cm}$ to $15 \mathrm{~cm}$ in Downstream. Meanwhile, the present study indicated that upstream was not disturbed which gave clear water than the downstream.

The depth measurement was statistically significant which was usually due to the fact that it's the part which holds water, while the downstream only releases the water when needed. The rainy season affects transparency due to flooding, surface runoffs and suspended materials that followed the rainfall [9].

Dissolved Oxygen fluctuated from $4.1 \mathrm{mg} / \mathrm{l}$ to 5.2 $\mathrm{mg} / \mathrm{l}$ to $6.1 \mathrm{mg} / \mathrm{l}$ in upstream and from $4.9 \mathrm{mg} / \mathrm{l}$ to $5.0 \mathrm{mg} / \mathrm{l}$ to $6.9 \mathrm{mg} / \mathrm{l}$ in Downstream, though the standard for dinking recommends $6 \mathrm{mg} / \mathrm{l}$, whereas for sustaining fish and aquatic life is 4.5 $\mathrm{mg} / \mathrm{l}$ is required [10].

BOD fluctuated from $13.7 \mathrm{mg} / \mathrm{l}$ to $15.8 \mathrm{mg} / \mathrm{l}$ to $16.4 \mathrm{mg} / \mathrm{l}$ in Upstream and from $13.8 \mathrm{mg} / \mathrm{l}$ to $14.9 \mathrm{mg} / \mathrm{l}$ to $17.9 \mathrm{mg} / \mathrm{l}$ in Downstream.

The conductivity of the water fluctuated from $30.4 \mu \mathrm{s} / \mathrm{cm}$ to $30.9 \mu \mathrm{s} / \mathrm{cm}$ to $31.6 \mu \mathrm{s} / \mathrm{cm}$ in Upstream and from $30.3 \mu \mathrm{s} / \mathrm{cm}$ to $31.5 \mu \mathrm{s} / \mathrm{cm}$ in Downstream the conductivity value was higher in Upstream than in Downstream.

pH fluctuated from 6.9 to 7.1 to 7.7 in Upstream and from 7.0 to 7.2 to 7.8. The $\mathrm{pH}$ value was higher in Downstream than in Upstream. Nutrients concentration of Goronyo Dam includes Nitrate, Ammonia and Phosphate concentrations respectively. For Nitrate it fluctuated from 0.4 $\mathrm{mg} / \mathrm{l}$ to $0.9 \mathrm{mg} / \mathrm{l}$ in Upstream and from $0.4 \mathrm{mg} / \mathrm{l}$ to $0.6 \mathrm{mg} / \mathrm{l}$ to $0.9 \mathrm{mg} / \mathrm{l}$ in Downstream. Unpolluted natural waters usually contain minute amounts of nitrate. Phosphate fluctuated from $0.2 \mathrm{mg} / \mathrm{l}$ to $0.3 \mathrm{mg} / \mathrm{l}$ in Upstream and was the same as in Downstream from $0.2 \mathrm{mg} / \mathrm{l}$ to 0.3 $\mathrm{mg} / \mathrm{l}$. Ammonia fluctuated from $0.6 \mathrm{mg} / \mathrm{l}$ to 2.8 $\mathrm{mg} / \mathrm{l}$ in Upstream and from $0.5 \mathrm{mg} / \mathrm{l}$ to $2.5 \mathrm{mg} / \mathrm{l}$ to $2.8 \mathrm{mg} / \mathrm{l}$ in Downstream; here Ammonia was higher in Upstream than in Downstream. All other physicochemical variables couldn't indicate any statistical significance apart from depth and transparency (Table 1 and 2).

Based on the results obtained from the Fishermen (Respondents) in Goronyo Dam, shows that majority of the respondents working in the area were within the age group of 16-25 and their main occupation was fishing. 
Table 1 - Variation of Physicochemical Properties at Upstream and Downstream of Goronyo Dam, Sokoto Nigeria 2016

\begin{tabular}{|l|c|c|c|}
\hline \multicolumn{1}{|c|}{ Parameters } & Upstream & Downstream & Sig difference \\
\hline Temperature $\left({ }^{\circ} \mathrm{C}\right)$ & 27.7 & 29.3 & N.S. \\
\hline Depth $(\mathrm{m})$ & 11.7 & 4.2 & $* *$ \\
\hline Ammonia $(\mathrm{mg} / \mathrm{l}))$ & 2.07 & 1.93 & N.S. \\
\hline Transparency $(\mathrm{cm})$ & 24.7 & 13.3 & $* *$ \\
\hline Phosphate $(\mathrm{mg} / \mathrm{l})$ & 0.23 & 0.23 & N.S. \\
\hline Nitrate $(\mathrm{mg} / \mathrm{l})$ & 0.73 & 0.63 & N. S. \\
\hline DO $(\mathrm{mg} / \mathrm{l})$ & 5.13 & 5.6 & N.S. \\
\hline BOD $(\mathrm{mg} / \mathrm{l})$ & 15.3 & 15.5 & N.S. \\
\hline Conductivity $(\mu \mathrm{s} / \mathrm{cm})$ & 31.0 & 30.7 & N.S. \\
\hline pH & 7.2 & 7.3 & \\
\hline
\end{tabular}

Notes: N. S. - No Significance difference; ${ }^{\star \star}$ - There is Significance difference.

Table 2 - Status of Physicochemical Properties of Goronyo Dam, Sokoto Nigeria, 2016

\begin{tabular}{|l|c|c|c|c|}
\hline \multicolumn{1}{|c|}{ Parameters } & Mean and SE & Min & Max & SD \\
\hline Temperature $\left({ }^{\circ} \mathrm{C}\right)$ & $28.3 \pm 1.45$ & 27.0 & 29.5 & 2.52 \\
\hline Depth $(\mathrm{m})$ & $7.92 \pm 2.02$ & 6.25 & 9.75 & 3.51 \\
\hline Ammonia $(\mathrm{mg} / \mathrm{l})$ & $2.0 \pm 1.45$ & 0.55 & 2.80 & 2.52 \\
\hline Transparency $(\mathrm{cm})$ & $19.0 \pm 3.61$ & 16.5 & 22.5 & 6.25 \\
\hline Phosphate $(\mathrm{mg} / \mathrm{l})$ & $0.23 \pm 0.67$ & 0.20 & 0.30 & 0.12 \\
\hline Nitrate $(\mathrm{mg} / \mathrm{l})$ & $0.68 \pm 0.30$ & 0.40 & 0.90 & 0.51 \\
\hline DO $(\mathrm{mg} / \mathrm{l})$ & $5.35 \pm 1.19$ & 4.00 & 4.50 & 6.50 \\
\hline BOD $(\mathrm{mg} / \mathrm{l})$ & $15.42 \pm 1.96$ & 6.80 & 13.75 & 17.15 \\
\hline Conductivity $(\mu \mathrm{s} / \mathrm{cm})$ & $30.83 \pm 0.73$ & 2.40 & 30.35 & 31.55 \\
\hline pH & $7.27 \pm 0.45$ & 1.50 & 6.92 & 7.70 \\
\hline
\end{tabular}

It also shows that most of the fishermen caught dead fish and those infected with diseases. Their main purpose of fishing in the area was to sell and feed their families and most of the fishermen work daily. The fishing gears used was fishnet, hook, and gill net which were used by most of the respondents. The mobility device that was mostly used by the respondents was calabash and wooden boat. Many of the fishermen in the area prefer catching of table size of fishes. Peak rainy season was recorded to be the one with the highest availability of fish species and rainy season was preferred season for fishing among the respondents. The main contribution in the dead of fishes according to respondents were predation and water pollution [13]. Abundant fish species from the survey were Mormyrops spp. followed by Alestes spp. and Clupeid spp. Contribution to healthy survival of fish was reported by the respondents to be an abundance of water and plankton. Distribution and availability of fish were noted to be affected by predators, fish diseases and poor water quality (Table 3 ).
Table 3 - Fish Diversity and Status of Goronyo Dam 2016, Sokoto Nigeria

\begin{tabular}{|l|l|c|c|}
\hline No & \multicolumn{1}{|c|}{ Species } & $\begin{array}{c}\text { Rainy } \\
\text { Season }\end{array}$ & $\begin{array}{c}\text { Dry } \\
\text { Season }\end{array}$ \\
\hline 1 & Hyperopisus bebe accidentalis & Present & Present \\
\hline 2 & Clarias anguillaris & ' & ' \\
\hline 3 & Clarias gariepinus & ' & ' \\
\hline 4 & Clarias lazera & ' & ' \\
\hline 5 & Alestes baremose & ' & - \\
\hline 6 & Schibe mystus & ' & - \\
\hline 7 & Melapterurus senegalus & ' & - \\
\hline 8 & Polypteprus annectens & ' & - \\
\hline 9 & Oreochromis niloticus & ' & - \\
\hline 10 & Micalestes acutidens & ' & ' \\
\hline 11 & Mormyrops rume & ' & ' \\
\hline 12 & Synodontis cambiensis & ' & - \\
\hline 13 & Tetraodoooon fahaka & ' & - \\
\hline 14 & Hydrocynus forskalii & ' & ' \\
\hline 15 & Gymmarchus niloticus & ' & - \\
\hline 16 & Bagrus docma niger & ' & ' \\
\hline 17 & Heterotis niloticus & ' & - \\
\hline 18 & Clupsisudis niloticus & Citharinus citharus & \\
\hline 19 & & ' & \\
\hline
\end{tabular}

Notes: Early Rainy Season - 1(3.00), Peak Rainy Season 10(33.00), Early Dry Season - 0(0.00), Peak dry Season 19(63.00) 
While the main factors that affect the survival of fishes in lentic water bodies are a shortage of water, pollution and predation [12].

The Trophic State Index of Goronyo Dam based on the results for the present study reveals that in June it was from 10.23 in Upstream and 13.5 in Downstream, while July it recorded 12.1 in Upstream and 16.54 in Downstream. In August the TSI was 13.0 at Upstream and 15.03 in Downstream, which shows that the Upstream has lower TSI than Downstream. From the result, it shows also that the dam is oligotrophic because it was less than 30 , which means the water has clear transparency and oxygen was available throughout the year at the hypolimnion [14]. The results of the TSI also indicated that downstream is likely to approach mesotrophic class (Table 4 and Table 5) from the TSI values obtained, this is due to the low transparency measurement which reflects its significance in the computation of TSI index.

Table 4 - Monthly Carlson's TSI at Upstream and Downstream of Goronyo Dam (June - August 2016)

\begin{tabular}{|l|c|c|l|}
\hline Months & Upstream & Downstream & $\begin{array}{l}\text { Carlson's } \\
(1977) \text { TSI } \\
\text { Classification }\end{array}$ \\
\hline June & 10.23 & 13.50 & $10-30=$ \\
July & 12.10 & 16.54 & Oligotrophic \\
& & & $\begin{array}{l}31-50= \\
\text { Mesotrophic } \\
51-70= \\
\text { August }\end{array}$ \\
& 13.00 & 15.03 & $\begin{array}{l}\text { Eutrophic } \\
71-90>= \\
\text { Hypereutophic }\end{array}$ \\
\hline
\end{tabular}

Notes: $<30-40=$ Oligotrophic, $40-50=$ Mesotrophic, 50-70 = Eutrophic, $70-100+=$ Hypereutrophic
Table 5 - Summary Statistics of Carlson's TSI of Goronyo Dam (June - August 2016)

\begin{tabular}{|l|c|c|}
\hline Statistical Variable & Upstream & Downstream \\
\hline Mean & 11.78 & 15.02 \\
\hline Standard Error & 0.81 & 0.88 \\
\hline Median & 12.10 & 15.03 \\
\hline Minimum & 10.23 & 13.49 \\
\hline Maximum & 13.00 & 16.54 \\
\hline
\end{tabular}

\section{CONCLUSION}

Water quality plays a vital role in the distribution, abundance and density of fish species. The survey reveals fish species to be more available in the dam during the rainy season than dry season. Excess of fishing activities may also lead the depletion of some species. The physicochemical parameters and productivity status observed shows that the dam was at oligotrophic class, though upstream is backward in terms of TSI status, but both upstream and downstream were at oligotrophic state during the study.

\section{REFERENCES}

1. Adeyemo, O. K., Adedokun, O. A., Yusuf, R. K., \& Adeleye, E. A. (2008). Seasonal changes in physicochemical parameters and Nutrient load of river sediments in Ibadan city, Nigeria. Global Nest Journal, 10(3), 326-336.

2. American Public Health Association, American Water Works Association, Water Environment Federation. (1999). Standard methods for the examination of Water and Wastewater. Retrieved from https://www.mwa.co.th/download/file_upload/SMWW_1000-3000.pdf

3. Bootsma, H. A., \& Hecky, R. E. (1993). Conservation of the African Great Lakes: A Limnological Perspective. Conservation Biology, 7(3), 644-656. doi: 10.1046/j.1523-1739.1993.07030644.x

4. Carlson, R. E. (1977). A trophic state index for lakes. Limnology and Oceanography, 22(2), 361-369. doi: 10.4319/lo.1977.22.2.0361 
5. Devi Prasad, A. G., \& Siddaraju, P. (2012). Carlson's Trophic State Index for the assessment of trophic status of two Lakes in Mandya district. Advances in Applied Science Research, 5, 2992-2996.

6. Downing, J. A., Plante, C., \& Lalonde, S. (1990). Fish Production Correlated with Primary Productivity, not the Morphoedaphic Index. Canadian Journal of Fisheries and Aquatic Sciences, 47(10), 19291936. doi: 10.1139/f90-217

7. Fee, E. J., Shearer, J. A., DeBruyn, E. R., \& Schindler, E. U. (1992). Effects of Lake Size on Phytoplankton Photosynthesis. Canadian Journal of Fisheries and Aquatic Sciences, 49(12), 2445-2459. doi: 10.1139/f92-270

8. Gelman, A. (2005). Analysis of variance? Why it is more important than ever. The Annals of Statistics, 33(1), 1-53. doi: 10.1214/009053604000001048

9. Henry, J. G., \& Heinke, W. G. (2005). Environmental Science Engineering (2nd ed.). New Delhi: Prentice Hall Publishers.

10. Kumar, A. (2005). Fundamentals of Limnology. New Delhi: APH.

11. Lake Country Wateratlas. (2017). Trophic State Index (TSI). Retrieved from http://www.lake.wateratlas.usf.edu/shared/learnmore.asp?toolsection=lm_tsi

12. Ranta, E. and Lindstrom, K. (1998). Fish Yield Versus Variations in Water Quality in The Lakes of Kuusamo, Northern Finland. Annales Zoologici Fennici, 35(2), 95-106.

13. Rothhaupt, K. O. (2000). Plankton population dynamics: food web interactions and abiotic constraints. Freshwater Biology, 45(2), 105-109. doi: 10.1046/j.1365-2427.2000.00679.x

14. Sarkar, B. C., Mahanta, B. N., Saikia, K., Paul, P. R., \& Singh, G. (2006). Geo-environmental quality assessment in Jharia coalfield, India, using multivariate statistics and geographic information system. Environmental Geology, 51(7), 1177-1196. doi: 10.1007/s00254-006-0409-8

15. Shuter, B. J., \& Ing, K. K. (1997). Factors affecting the production of zooplankton in lakes. Canadian Journal of Fisheries and Aquatic Sciences, 54(2), 359-377. doi: 10.1139/f96-270

16. Umar, A. S., \& Parakoyi, D. B. (2005). The prevalence and intensity of urinary schistosomiasis among school children living along the Bakalori dam, Nigeria. The Nigerian postgraduate medical journal, 12(3), 168-172.

17. Union of Concerned Scientists. (2003). Changes in Lake Productivity and Eutrophication. Retrieved from

https://www.ucsusa.org/sites/default/files/legacy/assets/documents/global_warming/lake_pr oductivity.pdf 